\title{
SJoP
}

\section{A reciprocity of care: a dialogical reflection on the artwork Winter.}

\section{JOHN MARK HAMMERSLEY, RACHEL DAVIES \& DANIEL SAUL}

The Scottish Journal of Performance

Volume 5, Issue 1; April 2018

ISSN: 2054-1953 (Print) / ISSN: 2054-1961 (Online)

Publication details: http://www.scottishjournalofperformance.org

To cite this article: Hammersley, J. M., Davies, R., and Saul, D., 2018. A reciprocity of care: a dialogical reflection on the artwork Winter. Scottish Journal of Performance, 5(1): pp.103-117.

To link to this article: http://doi.org/10.14439/sjop.2018.0501.12

This work is licensed under a Creative Commons Attribution 4.0 International License. See

http://creativecommons.org/licenses/by/4.0/ for details. 


\section{A reciprocity of care: a dialogical reflection on the artwork Winter.}

JOHN MARK HAMMERSLEY, RACHEL DAVIES \& DANIEL SAUL

DOI: 10.14439/sjop.2018.0501.12

Publication date: 6 April 2018

\section{Introduction}

The work Winter. is an artists' film by Rachel Davies and Daniel Saul, commissioned by Quarantine as the third in the quartet suite of primarily performance works: Summer. Autumn. Winter. Spring. that explore the themes of life, death and time (Quarantine, 2017). It features Mandy, who has been told she has terminal cancer, and addresses the film's themes through a series of conversational interludes juxtaposed with scenes and details from her everyday life. Quarantine are a theatre company that have been making work for over 25 years, led by the creative directors Richard Gregory and Renny O'Shea. They are known for creating theatre that explores everyday themes, and which grows out of working with the public. In Quarantine's work there is a respect for and love of people, which means they are able to get people up on stage and ask them to speak openly, without feeling they are putting them on the spot or exploiting them. They create a space for having conversations. The quartet was commissioned by: SICK! Festival, Compass Live Art, Contact, Dublin Theatre Festival, HOME, Göteborgs Dans \& Teater Festival, In Between Time, Lancaster Arts, National Theatre Wales, Noorderzon Performing Arts Festival Groningen, and Northern Stage; it was performed at the Old Granada Studios in Manchester in 2016 and at The Space as part of the Norfolk and Norwich Festival in 2017. The film Winter. was shown as part of The 
Art of Care-full Practice symposium in Glasgow in March 2017.

Winter. was made through a series of audio recorded conversations and film shootings in and around Mandy's home. In their first meeting, Davies asked Mandy if she would mind her recording their conversation. This unstructured conversation lasted for over four hours and provided the material for a planned, three-day shoot which included: recording Mandy at her kitchen window looking out onto the garden, taking the dogs out for a walk, another long interview, sequence shots of the garden at sunrise, and a portrait shot of Mandy. While producing a rough edit of Winter., Davies and Saul invited Mandy to visit London for the first time to do some studio slow motion shots of her sewing. However, as Mandy's health became worse, the trip was called off. Shortly after, Mandy received news from the doctors that there was nothing more they could do for her. Davies and Saul visited Mandy's home once more to share and show the work in progress, and conduct one more recorded conversation, as they felt Mandy might wish to add to what she had previously said. Mandy died a few months after the film premiered in Manchester, March 2016. After the quartet's showing in Norfolk in 2017, John Hammersley met the film-makers Davies and Saul to discuss and reflect on the process of collaborating with Mandy in the making of Winter. and to explore what insights about care might emerge from their dialogue.

Mandy's death raises the question of whether talking about the production of Winter. for the purpose of research risks constructing an objectified representation of Mandy, onto which the artists' ideas can be superimposed. Artistic and research representations may be reductive of the complexity of lifeworlds (Husserl, 1970) and their participants, unavoidably involving generalisations and selections. However, this text is offered as an artists' 
reflection of their experience of collaborating with Mandy. Hammersley's aim in this constructed account is to represent the dialogue with the artists Davies and Saul, and to convey some of the complexity of the dynamics of care that emerged in the process of making Winter.

Constructed research accounts are a feature of Hammersley's practice-based approach to dialogical research-as-art (Hammersley, 2015). Combining a Platonic maieutic (Leigh, 2007), a non-linear and multi-perspectival mode of written dialogue, with Wittgensteinian informed social constructionist approaches to meaning-making (Wittgenstein, 1958) allows for the preservation of multiple thematic concerns and perspectives in conversation. This seeks to avoid reducing concepts such as care to a singular authorial perspective or overly narrow definition. In this manner, dialogue is not construed as an argumentative exchange of reason between two interlocutors, but instead, as a multi-layered process of meaning-making that sustains tensions between ideas in an on-going process of knowledge performance. This promotes a more active and reflective consideration of the text. The implication is that a textual account of conversation does not mirror real events. Instead, this text is a performative act of representation and construction (Rhodes, 2000), and one of many possible accounts of the dialogical event of meaning-making between Davies, Saul and Hammersley. It is offered as a dialogue in which the reader is invited to actively participate and contribute further resources for interpretation.

\section{A dialogue}

Daniel: We use the word 'portrait' as a starting point.

John: Is it a film portrait of Mandy who has terminal cancer? 
Rachel: Richard, who runs Quarantine, proposed the film to me. He put it in the themes of the quartet Summer. Autumn. Winter. Spring. which are about the human lifecycle and our relationship with time and hope. He wanted Winter. to be about time, but through the experience of someone who knows that it is acutely precious-a younger person, Mandy, whose time is cut short and knows it.

D: He used the phrase 'close-up' which really informs the work. In terms of art-language, it is a portrait, and in filmlanguage, it is a close-up. They wanted a big screen close-up of one person in contrast to Summer. which comes before, which has lots of people on stage. Winter. has one person on screen looking at the audience, but the viewer is very conscious of that person being magnified.

$\mathrm{R}$ : This was looking at one person's life and using it as a microcosm. There is always the thought that this person's experience, even though it is particular, hopefully resonates with all. That's not to describe too much, or to become too much her story. It doesn't become about her survival. It tries to point to the themes of life, death, and time, which Richard stated at the start. We were talking about value with Richard and he mentioned a friend who had a terminal illness. His friend said that things that were small took on the biggest value, taking pride in making a nice meal, or watching the kids drawing.

D: Finding the profound in amongst the small things is a theme throughout the quartet of works, but we also use objects to symbolise human experience and relationships. Small objects became a theme we picked up upon within the film. We used a split screen approach, juxtaposing objects and details alongside Mandy talking to or looking at the camera. You might notice the detail of smudges on a window. It talks about Mandy's world closing in and getting smaller. 
J: As film-as-theatre it is constructed through complicated relationships, but it is largely performed through voice, and at some level, it feels like a theatrical monologue; but at the same time I wonder about whether this is Mandy voicing her own monument?

D: It is something we have both done a lot in our work. A lot of the conversations that make up the soundtrack were recorded with just a little sound recorder.

R: I didn't want to make a film about watching somebody dying. I didn't want it to be, 'Oh you can see she's getting worse', or that sort of thing, and I think we got that from Mandy. I think she interpreted it as a monument, yes. I think she wanted that. She always said, 'I want to leave something'.

J: How were you introduced to Mandy?

R: With Quarantine we discussed who might be the subject of this film. Richard said we would be making it with SICK! Festival, and they have their networks to find someone to work with, but he said, 'does anyone know anybody who they think might be interested?'. Lisa said, 'Well there's my auntie Mandy. In our family, she's really looked down on. She's got four dogs. She's got bad sight. She's a bit deaf. She just works in Asda'. She portrayed the family attitude to her favourite auntie Mandy.

D: She said her family call her common.

R: Yes, [Lisa said] 'in our family she's called common'. This might be describing Lisa's relationship to her parents which is estranged. So, immediately it is a very complicated personal relationship. Lisa was crucial to building a bridge between ourselves and Mandy; she was continuously there 
as someone to refer to, to ask how Mandy might feel about things. She had an intimate knowledge of how to adapt our needs to Mandy's needs. Lisa is a film maker, as well as being Mandy's niece and working for Quarantine. And that's quite common to how they work. Quarantine often approach participants for projects by starting with its wider family, the members' families and friends, as they believe this helps establish relationships of trust.

J: Do you think there are risks working with vulnerable people we know?

$\mathrm{R}$ : I think it has got to come down to the particularities of that specific relationship. Lisa wholeheartedly had Mandy's care centrally in her mind. That was clear.

$\mathrm{J}$ : Is care just about good intentions, or is care about having deeper insights into the risks of projects?

R: At this stage, nothing was assumed. The conversation was very careful, and Richard was particularly careful about rushing in. It was very gentle, 'Perhaps, would a conversation with Mandy be appropriate, to talk to her about Quarantine?'. And Mandy knows what Quarantine do, and she knows Lisa, and so it is... I mean obviously that is open to exploitation.

J: Are vulnerable relationships open to exploitation by us as artists, or do we use our family and friends?

R: Obviously it could be the first, but in this case, I don't think it was that. But yes, if you were hell-bent on trying to fashion a story out of something, or just get something on the screen. But I can confidently say that none of that was there in this case. 
J: Such works can be read as using our relationships as an artistic resource, but conversely, they can be seen as a participatory act of giving; our relatives giving to us, as support. It isn't just mining or exploitation if there is an understanding of what it is for. You were suggesting that Mandy knew what Quarantine did.

R: Yes, because she knows Lisa incredibly well.

$\mathrm{J}$ : There is still a question of pace, of not rushing, and was that important in enacting the care in the work, the pace of starting out, making decisions?

$\mathrm{R}$ : Yes. That was as long as it took, and yes, in reality, you are working to a deadline, but we had lots of time. It wasn't like we had to pressure her to agree. It wasn't like that. It was, 'let's find out', instead of, 'let's go with this subject'. There was quite a lot of time when we went away, and thought, and then I went up and met her before anything had been established or suggested, really.

J: Early on, with Quarantine, were there conversations about the risks?

$\mathrm{R}$ : Of course. Those conversations weren't formalised in any way, but 25 years into Quarantine, they are absolutely full of them, as they know the territory.

D: Can I just interject? Because there were conversations with Dr John Troyer from the University of Bath, which were happening before your meeting. He was involved in the conceptualising of the quartet, and when Quarantine started talking about working with someone close to dying, they did go straight away to talk with John, and they had a lot of ethical conversations which, funnily enough, we weren't 
part of, but the company did explicitly talk about risks at that point.

$\mathrm{J}$ : But, when I see the work in a theatre, I see an edited film piece, I don't see a work that is constructed through many layers of careful conversation. I am curious about representing the complexity of care. I wonder about how risky this work would be for an individual, or just you two working in isolation, because you talk about the unique relational situation of this work.

D: One of the things which is very important is Lisa's introduction to the film which you see on a display in the theatre. So just before the screen is brought on to stage, she is typing.

R: She says, 'Hi I'm Lisa, I've been at the back all the time. The film you are about to see is about my favourite auntie. When I was 11, I chained myself to the fence because I didn't want to leave'. So, it was just a little statement about how much she meant to Lisa, and now she says that she has died, relatively recently, in July last year.

$\mathrm{J}$ : Mandy's reflections remind me of epimeleia, a concern with care for oneself that is more than self-interest, it is part of the art of life, or paying attention to what is important in life (Rabinow, 2000). Do you think Winter. and the quartet represent life as a shared work of art, that the things we make are all part of constructing our lives artistically?

D: Yes. We are only as much as the stories we tell ourselves.

R: That links to how much impact making this film has had on my life. It has had a big impact on me. I feel absolutely energised and empowered. I was brought into a very 
privileged role to work with Mandy, and it was a big experience for me as well. There is an aspect of care, of the ripples of impact that it has had on my life. And I have written a little bit about how I felt coming back after the second shoot. I had a conversation with Dan and I just felt awful. It was just half an hour before our taxi was coming to take us home, having to be on a certain train and I am aware of what Mandy is going through, she needs to go to hospital to find out why she has lost feeling in her right side, and she is very worried that the cancer has gone to her brain. So, she expressed that during the day, and as I say, we've got a job to do. A job of not only being commissioned by Quarantine, but a job that Mandy is expecting us to do and wanting us to do. I have got a film to make, and I have ideas which need to be in that film to best portray the beauty that I want to convey, predetermined or whatever, but I need to do it justice within my set of criteria that means a good film. So, I felt terrible. I said we need more close ups of the wallpaper, and we need more sounds of the dogs, but it has been known from that morning that she felt quite bad that day. So, she is going to go off to hospital as we got on the train, but she hadn't been given the big news which came after the visit, which was that there was nothing more they could do for her. In the film, she is talking about possibly having two years left, but she actually had two months. Very soon after we made the film she died, and that is common with lung cancer, it can go very quickly to the brain.

$\mathrm{J}$ : You are trying to care for the work of art and for yourself as an artist, but you are almost in a therapeutic role of listening. Mandy is telling you about her concerns; she has family, she has a niece, but she is telling a film maker about her concerns.

R: And the care side of things which resonated with me is as a mother also. She is a mother of two children, so that was the involvement I felt wrapped up in. So, there are conflicts, 
and there are going to be, aren't there? You're a human being, you can't really divide and you can't compartmentalise completely. But I would also say I didn't feel adrift in that. Lisa had been with us all the time. Lisa and Lisa's partner were there as people who knew Mandy well. So, I felt, to a degree, able to function in my role as a film director.

D: My perspective is that we absolutely went through a crisis of confidence about the project at that moment, which looking back on it, was part of the process for us. I just noticed one of those awful ironies that one person is going through a life-changing piece of bad news, and at that particular moment our concentration was in the details, and it brought about that questioning. We asked ourselves, 'are we using someone else's life, are we exploiting someone else's life to make a piece of art?', and for me, at that moment, we didn't know the answer, and I felt bad because a project that we had felt quite confident in, and felt that it was a caring project, suddenly came into question.

R: It didn't come into question for me, I just let myself feel those feelings. I didn't feel wrong, I just acknowledged the feelings which are complex, and which are probably part of what any documentary maker might go through.

$\mathrm{J}$ : Was any care offered to you?

R: Yes. I spoke to Richard about the feeling. I said, 'this is quite tough at this stage. I am feeling quite affected', and he said, 'we've been working with John Troyer, talking about how these things might affect the making and whether you would like to talk to someone about this, whether you feel John is the person, or some other form of counselling. Can we suggest that to you?', and I said I'd think about that. I think that helped me to think it is part of things, and I don't 
think I developed that need, but I was quite conflicted for a while.

D: I was quite conflicted for weeks. But I also think it is a really good thing to do because you don't take things for granted, and you do engage critically in the process.

$\mathrm{J}$ : Is it a key part of the work that it can only be made with someone who is likeable, that we can care about?

D: No. I don't think so.

R: It would be a different film with a different person. Any person different from Mandy, we would notice different things.

$\mathrm{J}$ : But is it important that the viewer cares for Mandy?

$\mathrm{R}$ : Well that is a question about what constitutes caring for, whether it is about thinking that person is a bit like them, and I don't think it is.

D: I don't think it is either, but I do think it is important that people empathise with Mandy on some level.

R: But if we had been introduced to someone who it was very hard to like on those surface levels, then I think we'd have certainly found ways to work with that, and ideas of empathy.

D: There have been a lot of documentary films specifically about people with cancer, and there are quite a lot online made by relatives that tackle a very parallel area. 
J: I wonder how many of those relatives are also artists? It raises issues of representation: what does it mean to represent someone in portraiture, in documentary, to represent somebody dying? What are the risks of representation?

R: It leads me to think about how and why Lisa wasn't making the film.

D: Which was a conversation we used to have quite regularly.

J: What do you think about that now?

$\mathrm{R}$ : Some of the complexities we were just talking about would be far bigger, I think Richard thought that might have been too close. Maybe it was something that wouldn't have been helpful for Lisa.

J: Could filming be a deflection, seeing things through the camera but not being present as a grieving person?

R: Indeed, having a kind of filter that distracts, and there are big stresses involved in delivering a product on time that could complicate the grieving process. It would have been very complicated for Lisa to make the film. She is a niece, and this is about family dynamics and rivalries, potentially. There is a complex relationship between Lisa and Mandy's children. How might Lisa have started to feel with the building relationship she was having with the reconciled children?

J: To what extent do you think the care you showed Mandy in constructing the film might obscure her anger, the grief, the 
hurt and create a representation of the end of life that edits those things out?

D: I don't know because there is a lot in the film where she talks about her siblings and her parents which is absolutely about her anger, and she talks about how that will never be resolved now. It finishes on the unfinished garden just after she has talked about how she will never be able to heal the bonds with her siblings.

$R$ : And that she is not ready to go, and she says, 'I can't possibly die until I've done these things'. So, it is left with that. I do think she is like us all. She knows she is being filmed. She is a performer. There is also a kind of censorship to that. I didn't want to push and push and push. I was listening more than asking questions. I wanted to take what she wanted to give me and make something from that. I didn't want to think there must be more. That was a care that I had. It wasn't an interview. It was a listening.

D: We had lots of very loose questions.

$\mathrm{R}$ : We called it an interview, but I wasn't trying to shape it into anything. You are aware of themes you are trying to get at.

D: We like to expand the term documentary, as I like responding to material, which for me is analogous to listening in how we approach documentary. With filmmaking, you go and gather the material. Then you bring it back to the edit suite, and then you spend ages listening and listening, over and over again, and rereading transcripts. Because sometimes, when you're in a conversation, you are not really listening. You are sometimes thinking about 
what's going on for you. Taking it home, you can think about it in a new way.

\section{References}

Hammersley, J.M., 2015. Dialogue as practice and understanding in contemporary art. PhD. Cardiff Metropolitan University.

Husserl, E., 1970. The crisis of European Sciences and transcendental phenomenology: an introduction to phenomenological philosophy. Trans. David Carr. Evanston: Northwestern University Press.

Leigh, F., 2007. Platonic dialogue, maieutic method and critical thinking. Journal of Philosophy of Education, 41(3), pp.309-323.

Quarantine, 2017. Summer. Autumn. Winter. Spring. [online] Available at: 〈https://qtine.com/work/summer-autumn-winter-spring/〉 [accessed 2 December 2017].

Rabinow, P. ed., 2000. Michel Foucault: Ethics, essential works of Foucault 1954-1984 Volume 1. London: Penguin Books.

Rhodes, C., 2000. Ghostwriting research: positioning the researcher in the interview text. Qualitative Inquiry, 6, pp.511-525.

Wittgenstein, L., 1958. The blue and brown books: preliminary studies for the 'philosophical investigations'. Oxford: Blackwell.

\section{About the authors}

RACHEL DAVIES makes moving image for various contexts from artist's film to immersive installation. She has authored or collaborated on over 100 productions with international artists including Akram Khan, Áine Phillips, Quarantine and Protein Dance Theatre. Rachel studied at the Royal College of Art. She has been a Place Associate Artist, Manchester University Drama Fellow, DanceDigital Associate Artist, and she is currently Lecturer / Researcher in Design at Kingston University. Her work has been commissioned by Channel 4, BBC, Arts Council England, Manchester International Festival and Sadlers Wells Theatre; it has won major international awards and is in British Council film collections. Winter. was co-directed by Rachel Davies and Daniel Saul (R\&D Studio). http://www.rachelanddaniel.co

JOHN MARK HAMMERSLEY is an independent artist-researcher whose work is focused on dialogue as art practice. He holds a PhD in Fine Art from Cardiff Metropolitan University and is a founding member of the network-artwork The Dialogic, and affiliate member of the British Psychological Society's Community Psychology and Qualitative Methods in Psychology Sections. 
DANIEL SAUL is a film-maker whose work is rooted in painting, animation and participatory art. Most of his current work is in film projects with a documentary starting point, expanded with poetry, animation, theatre, and dance. Frequently concerned with biography, Daniel uses a variety of disciplines and modes of expression to reveal hidden strata that make up the narratives of our individual and collective lives. In 2016, together with artist film-maker Rachel Davies, Daniel founded R\&D Studio to make collaborative work. 